\title{
UPAYA PENGENDALIAN RISIKO PADA UNIT PENGELOLAAN LIMBAH MEDIS BENDA TAJAM DI RUMAH SAKIT
}

\author{
Sacharina Surya Ningrum ${ }^{1}$, Abdul Rohim Tualeka ${ }^{2}$ \\ ${ }^{1}$ Program Studi S1 Kesehatan Masyarakat, Fakultas Kesehatan Masyarakat, Universitas Airlangga \\ ${ }^{2}$ Departemen Keselamatan dan Kesehatan Kerja, Fakultas Kesehatan Masyarakat, Universitas \\ Airlangga \\ sacha.rina@yahoo.com
}

\begin{abstract}
Unit medical waste management is a work in hazardous or high risk for workers. Hazards faced by workers waste management unit derived from the mechanical and physical danger. In order to do proper hazard control, it is necessary to do a risk assessment of the potential hazards. This study to determine and identify risk management of medical waste management in RS. X.The present study used observational descriptive method and applied cross-sectional approach. The primary data were collected from observation and interview, and the secondary data were gained from sanitation unit in RS. X. The object is research was medical waste management jobs. The interviewees were 6 medical waste management workers. The data, were analyzed descriptively were presented in table and compared to the applied theory and existing standart. The reference of method for risk assessment was risk management theory. The analysis of the data showed that there were 9 hazards identified, out of the total number of risk assessment discovered in the data, 7 hazards were categorized as low-risk, and 2 hazards were categorized as medium risk. Furthermore, risk assessment, education and training, rotation work shifting, company policies, and supply of personal protection equipment were already existed in the hospital. It is suggested that the hospital provide some futher controlling improvements, such as safety sign, routine inspection, medical checking, housekeeping, and providing personal protective equipment, such us apron and dust masker.
\end{abstract}

Keywords: risk control, medical waste management workers.

\begin{abstract}
ABSTRAK
Unit pengelolaan limbah medis merupakan pekerjaan yang membahayakan atau berisiko tinggi bagi pekerja. Bahaya yang dihadapi pekerja unit pengelolaan limbah berasal dari bahaya mekanik dan fisik, agar dapat dilakukan pengendalian bahaya yang tepat, maka perlu dilakukan risk assessment terhadap potensi bahaya yang ada. Penelitian ini bertujuan untuk mempelajari manajemen risiko dan mengidentifikasi manajemen limbah medis di Rs. X. Penelitian ini termasuk penelitian observasional deskriptif dengan pendekatan cross sectional. Data primer dikumpulkan dengan observasi dan wawancara serta data sekunder yang diperoleh dari instalasi sanitasi di RS. X. Objek penelitian ini adalah pekerjaan pengelolaan limbah medis. Sumber informasi adalah 6 orang pekerja pengelola limbah medis. Data yang diperoleh kemudian dianalisis secara deskriptif dengan menggunakan tabel dan dibandingkan dengan standart dan teori yang ada. Metode yang digunakan dalam melakukan risk assessment mengacu pada teori manajemen risiko yang selanjutnya hasil digunakan untuk pengendalian risiko. Hasil penelitian menunjukkan ada 9 bahaya yang teridentifikasi, dengan hasil penilaian 7 bahaya kategori risiko rendah dan 2 bahaya dengan kategori risiko sedang. Pengendalian risiko yang sudah dilakukan RS. X yaitu pengendalian teknik yaitu penggantian kantong plastik sampah diganti dengan yang kantong plastik yang lebih tebal, lalu pengendalian administrasi dilakukan pendidikan dan pelatihan tentang bekerja secara aman, memasang rambu K3, pemasangan label bahan kimia berbahaya, dan pengadaan alat pelindung diri seperti safety shoes, sarung tangan dan pakaian kerja.
\end{abstract}

Kata kunci: pengendalian risiko, pekerja pengelolaan limbah 
Sachrina, et al. Upaya Pengendalian Risiko Pada Unit Pengelolaan Limbah Medis Benda Tajam di Rumah Sakit
JPH RECODE Maret 2018; 1 (2) : 98-108 http://e-journal.unair.ac.id/JPHRECODE

\section{PENDAHULUAN}

Limbah medis memiliki bahaya utama yaitu risiko infeksi dari mikroorganisme yang terdapat dilimbah tersebut, infeksi terjadi dikarenakan terkena tusukan benda tajam. Hepatitis B, hepatitis C bahkan sampai HIV/AIDS merupakan ancaman yang paling serius jika terkena tusukan limbah medis benda tajam (Blenkharn, 2006). Limbah medis benda tajam beresiko besar menimbulkan kecelakaan dan penyakit jika tidak diolah dengan baik dan benar.

Limbah medis adalah limbah yang berasal dari perawatan gigi, farmasi, pelayanan medis atau yang sejenis, perawatan, pengobatan, atau pendidikan yang menggunakan bahan-bahan yang infeksius berbahaya atau bisa membahayakan, kecuali apabila terdapat pengamanan tertentu (Adisasmito, 2007). Hasil produksi limbah medis limbah medis di RS. X pada tahun 2014 $\pm 120 \mathrm{~kg}$ perhari, $\pm 3.600 \mathrm{~kg}$ perbulan, sehingga untuk total pertahun $\pm 43.200 \mathrm{~kg}$ pertahun. Gambaran tersebut dapat disimpulkan bahwa RS. X mempunyai potensi besar untuk menimbulkan kecelakaan kerja, penularan penyakit pada pekerja limbah serta lingkungan menjadi tercemar. Hasil penelitian yang dilakukan jika proses pengelolaan limbah medis tidak dilaksanakan sesuai dengan standart prosedur.

Kesehatan dan Keselamatan Kerja sampai saat ini belum menjadi prioritas penting terutama pada pengelolaan limbah medis. RS. $\mathrm{X}$ lebih mementingkan kelangsungan usaha, keuntungan, pemenuhan kebutuhan logistik, sumber daya manusia dan pengembangan jenis pelayanan kesehatan terbaru. Pekerja rumah sakit, seperti tim pengelolaan limbah, dokter, perawat, petugas radiologi, petugas laboratorium dan petugas kesehatan lainnya beresiko tinggi mengalami penyakit akibat kerja atau kecelakaan kerja yang belum mendapatkan perhatian cukup. Salah satu contoh kurang perhatiannya pihak rumah sakit terhadap pekerjanya adalah kurang diperhatikannya pengolahan limbah medis benda tajam yang berasal dari kegiatan pelayanan kesehatan yaitu masih ditemukan limbah medis pada bak sampah non medis, kurangnya kesadaran pemakaian alat pelindung diri pada petugas pengelolaan limbah serta masih kurang tersedianya sarana dan prasarana yang ada di rumah sakit tersebut. Berdasarkan penelitian yang telah dilakukan oleh Pratiwi dan Chatila (2013) terdapat sebuah tempat pelayanan kesehatan yang belum menyediakan alat pelindung diri pada pekerja pengelolaan limbah Oleh karena itu perlu dilakukan Risk Assessment beserta upaya pengendalian risiko di Rumah Sakit. Hal ini dimaksudkan agar risiko atau bahaya dapat dicegah atau dikendalikan. Sehingga dampak kerugian akibat penyakit dan kecelakaan kerja pada pekerja limbah medis benda tajam dapat diminimalisir.

Limbah medis benda tajam juga memiliki potensi risiko paling besar dalam penularan penyakit infeksi dan penyakit menular baik terhadap perawat atau pekerja rumah sakit maupun pengunjung RS. Pada RS. $\mathrm{X}$ terdapat pengelolahan limbah medis, dimana sistem pengelolahan limbah medis benda tajam masih kurang memerhatikan keselamatan pekerja, yang nantinya akan berdampak pada keselamatan dan kesehatan pada pekerja, masyrakat dan lingkungan sekitar. Tahap pengelolaan limbah medis benda tajam yang dimulai dari tahap pemisahan, pada tahap pemisahan sering kali terjadi kesalahan antara pemisahan limbah medis dan non medis. Berdasarkan hasil penelitian Sudiharti dan Solikhah (2013) jika tingkat pengetahuan yang dimiliki pekerja tentang perbedaan limbah medis dan limbah non medis serta cara pemilahannya kurang, maka akan dapat menimbulkan kecelakaan kerja.

Hasil penilitian oleh Alatas (2013) mengungkapkan bahwa pemisahan masih sering dilakukan oleh pihak pekerja untuk memisahkan, jarum dengan spuit, sehingga akan mengakibatkan bahaya potensial tertusuk. Penampungan sementara dilakukan di tiap-tiap ruangan, tahap pengangkutan sampah, hingga tahap pemusnahan limbah medis benda tajam dengan menggunakan incinerator. Akan tetapi Incenerator pada RS. X tidak digunakan lagi terkait beberapa alasan, oleh karena itu pihak RS. $X$ menggunakan pihak ketiga yaitu perusahaan yang memiliki incenerator untuk memproses limbah benda tajam sampai ke proses akhir. Apabila pengelolaan limbah medis benda tajam berjalan dengan baik, maka dapat membantu pencegahan penularan penyakit menular seperti HIV/AIDS hepatitis, dan lain-lain.

Mengingat pentingnya pengelolaan limbah medis benda tajam, RS. X harus melakukan pengelolaan limbah medis sesuai dengan standart prosedur. guna membantu 
mengurangi dampak risiko penularan penyakit melalui kontak dengan limbah maupun penyebaran kuman yang berasal dari limbah tersebut serta dapat membantu mewujudkan lingkungan rumah sakit yang aman dan bersih, maka salah satu usaha yang perlu dilakukan untuk menangani potensi bahaya yang ditimbulkan adalah melakukan penilaian dan pengendalian risiko. Proses penilaian risiko dimulai dari identifikasi bahaya, penilaian risiko awal, pengendalian kontrol dan penilaian risiko sisa. Tindakan pengendalian risiko yang tepat agar tercipta kondisi lingkungan kerja yang aman. Dengan dilakukan upaya penilaian dan pengendalian risiko ini, diharapkan bisa dijadikan referensi untuk meminimalkan angka kejadian penyakit dan kecelakaan kerja, maka diharapkan juga perhatian khusus dari lembaga-lembaga pelayanan kesehatan.

Tujuan penelitian ini adalah meng pengelolaan limbah medis benda tajam, mengidentifikasi bahaya pengelolaan limbah medis benda tajam, mengetahui terhadap tingkat risiko pengelolaan limbah medis benda tajam, mengetahui pengendalian risiko pengelolaan limbah medis benda tajam di RS. $\mathrm{X}$.

\section{METODE}

Penelitian ini termasuk dalam deskriptif karena penelitian ini dilakukan dengan tujuan untuk mempelajari tentang keadaan secara objektif. Sedangkan berdasarkan waktu penelitian termasuk desain studi cross sectional, yaitu penelitian yang menekankan pada waktu pengukuran atau observasi hanya satu kali pada satu saat. Desain studi cross sectional diharapkan dapat memberikan gambaran sekilas tentang populasi studi serta keterkaitan antar variabel yang akan diteliti. Tidak semua subjek penelitian harus diobserbvasi pada hari atau waktu yang sama, akan tetapi baik setiap variabel dinilai hanya satu kali saja. Berdasarkan cara pengumpulan data maka penelitian ini termasuk observasional (Nursalam, 2008).

Populasi adalah keseluruhan objek penelitian yang diteliti (Notoatmodjo, 2005). Total populasi pada penelitian ini adalah petugas pengelolaan limbah d RS. X yang berjumlah 6 orang. Lokasi penelitian di RS. X. Penelitian ini dilaksanakan pada bulan Februari 2015-Januari 2016. Variabel yang digunakan dalam penelitian adalah limbah medis benda tajam, pengelolaan limbah medis benda tajam, identifikasi bahaya, karakteristik tingkat risiko dan pengendalian risiko.

Sumber data yang digunakan dalam penelitian adalah sumber data primer dan sekunder. Data primer yang diperoleh dari hasil observasi, melakukan penilaian risiko terhadap pengelolaan limbah medis benda tajam dan wawancara. Peneliti menjelaskan tentang tujuan penelitian kepada responden, kemudian jika responden memahami dan menyetujui dapat menandatangani inform consent. Kemudian dilakukan observasi tentang penilaian risiko terhadap pengelolaan limbah medis benda tajam terhadap 6 responden petugas pengelolaan limbah di RS. $\mathrm{X}$.

Analisis data yang dilakukan adalah secara deskriptif dengan cara mendokumentasikan dan mengobservasi aktivitas responden pada pengelolaan limbah medis benda tajam untuk mengetahui potensi bahaya, mengobservasi pengendalian risiko yang sudah diterapkan dirumah sakit agar mengurangi risiko, kemudian hasil tersebut akan dilakukan risk assessment. Setelah dilakukan risk assessment yaitu dengan mengidentifikasi bahaya pada proses pengelolaan limbah setelah itu melakukan penilaian risiko, sehingga akan di dapatkan karakteristik risiko, setelah adanya hasil tersebut maka akan dilakukan pengendalian risiko.

\section{HASIL}

\section{Gambaran Umum RS. X}

Pelayanan kesehatan merupakan salah satu kebutuhan vital masyarakat. Saat ini biaya pelayanan kesehatan semakin tinggi, sehingga mengurangi akses masyarakat untuk menjangkau layanan kesehatan yang dibutuhkan. Di tengah-tengah keadaan ekonomi yang semakin sulit, tersedianya layanan kesehatan yang cukup dengan tarif rasional terjangkau inilah yang saat ini sangat dibutuhkan oleh masyarakat. Latar belakang RS. X yang berlokasikan Sidoarjo ini didirikan dengan harapan memberikan solusi bagi masyarakat untuk mendapatkan pelayanan kesehatan yang standart dengan tarif rasional yang terjangkau dengan pelayanan medis dan non medis secara professional dan bertaraf internasional. 
Berdasarkan jenis pelayanan yang diberikan, RS. X dikategorikan dalam rumah rakit umum, yaitu rumah sakit yang memberikan pelayanan kesehatan pada semua bidang dan jenis penyakit. Visi rumah sakit yang bertajuk islami dan pelayanan profesional menuju taraf internasional. Misi RS. X meningkatkan kualitas sumber daya manusia sesuai dengan kemampuannya. Selalu memberikan pelayanan secara professional baik pelayanan medis dan non medis. RS. X Pengelolaan Limbah Medis Benda Tajam

Tabel 1. Pengelolaan Limbah Medis Benda Tajam

\begin{tabular}{ll}
\hline \multicolumn{1}{c}{ Variabel } & \multicolumn{1}{c}{ Kriteria } \\
\hline Pemisahan & $\begin{array}{l}\text { Pemisahan limbah medis benda tajam kurang baik, karena } \\
\text { masih ditemukan jarum suntik tidak dipisahkan dengan spet, } \\
\text { sampah medis dan non medis tercampur. }\end{array}$ \\
\hline Penampungan sementara & $\begin{array}{l}\text { Pengumpulan limbah medis dengan kriteria penilain sudah } \\
\text { baik dan memenuhi semua kriteria yang terdiri dari kontainer }\end{array}$ \\
& yang tahan tusuk, kokoh, aman, bahan tidak mudah terbakar, \\
& diletkakkan sedekat mungkin berada dengan tempat dimana \\
peralatan medis benda tajam banyak digunakan.
\end{tabular}

\section{Identifikasi Bahaya}

Identifikasi bahaya adalah proses yang dilakukan untuk mengenali seluruh keadaan yang memiliki potensi penyebab penyakit dan kecelakaan akibat kerja yang timbul di tempat kerja. Identifikasi bahaya potensial di pengelolaan limbah medis sebelumnya belum pernah dilakukan sehingga belum diketahui Tabel 2. Identifikasi Bahaya di Pengelolaan

\begin{tabular}{lll}
\hline \multicolumn{1}{c}{ Langkah Kerja } & \multicolumn{1}{c}{ Bahaya } & \multicolumn{1}{c}{ Potensi Bahaya } \\
\hline Pemisahan & Jarum Suntik & Tertusuk \\
\hline & Tumpahan Cairan Infus & Terpeleset \\
\hline Penampungan Sementara & Botol ampul & Tergores/Tersayat \\
\hline & Tutup Troli & Tertusuk \\
\cline { 2 - 3 } & Penempatan Troli tidak pada tempatnya & Terbentur \\
\hline Pemindahan & Pengangkutan yang kurang hati2 & Tertimpa limbah Medis \\
\cline { 2 - 3 } & Tutup Troli & Tergores pecahan Botol \\
\hline
\end{tabular}

setiap potensi bahaya yang ada di lingkungan kerja serta tingkat risiko dari setiap bahaya tersebut. Hasil identifikasi bahaya dengan metode Job Safety Analysis (JSA) di Pengelolaan Limbah Medis Benda Tajam di RS. X yaitu: memiliki semboyan yaitu kesembuhan dan kepuasan pasien adalah segalanya bagi kami. Tujuan RS. X Terwujudnya faedah dan sejahtera pada umat manusia. RS. X memiliki fasilitas, sarana dan prasarana yang secara lengkap dengan waktu 24 jam diberikan oleh pihak RS. Proses Pengelolaan limbah pada RS.X incinerator tidak dapat digunakan, dan menggunakan pihak ketiga. 
Berdasarkan Tabel 2 Terdapat 9 bahaya potensial pada pengelolaan limbah medis benda tajam yaitu, 3 bahaya potensial pada tahap pemisahan, 3 bahaya potensial pada tahap penampungan sementara dan 3 bahaya potensial pada tahap pemindahan.

\section{Penilaian Risiko}

Penilaian risiko pada bagian pengelolaan limbah medis benda tajam bertujuan untuk menilai seberapa besar tingkat risiko yang ada. Tingkat risiko diperoleh dari matriks antara likelihood yakni kemungkinan bahaya tersebut terjadi dengan severity yakni keparahan dampak yang ditimbulkan dari bahaya tersebut. Penilaian likelihood didasarkan dari hasil pengamatan dan ditunjang dari hasil wawancara dengan tim pengelolaan limbah. Berikut ini hasil penilaian risiko:

Tabel 3. Penilaian risiko Pengelolaan Limbah Medis Benda Tajam

\begin{tabular}{llcc}
\hline \multicolumn{1}{c}{ Langkah Kerja } & \multicolumn{1}{c}{ Dampak Bahaya } & Nilai Risiko & $\begin{array}{c}\text { Ting- } \\
\text { katan Risiko }\end{array}$ \\
\hline Pemisahan & Tangan cidera, tangan berdarah & 6 & $\mathrm{M}$ \\
\cline { 2 - 4 } & Cidera & 2 & $\mathrm{~L}$ \\
\cline { 2 - 4 } & Luka ringan & 4 & $\mathrm{~L}$ \\
\hline Penampungan Sementara & Tangan cidera, tangan berdarah & 6 & $\mathrm{M}$ \\
\hline & Luka ringan & 1 & $\mathrm{~L}$ \\
\hline & Cidera & 2 & $\mathrm{~L}$ \\
\hline Pemindah-an & Cidera pada kaki dan tangan & 2 & $\mathrm{~L}$ \\
\hline & Cidera tangan & 1 & $\mathrm{~L}$ \\
\hline & Cidera & 3 & $\mathrm{~L}$ \\
\hline
\end{tabular}

Berdasarkan tabel 3 hasil penilaian risiko dari pekerjaan pengelolaan limbah medis benda tajam di RS. X bahwa risiko paling banyak yaitu tingkat risiko Low (rendah) dengan $7(77,8 \%)$ bahaya potensial, sedangkan untuk risiko Medium (sedang) 2 (22,2\%) bahaya potensial dan tidak diketemukan risiko High (tinggi). Sehingga tingkatan risiko pada RS.X masih tergolong risiko Low (rendah).

\section{Pengendalian Risiko}

Upaya pengendalian yang telah dilakukan oleh RS. X yaitu pengendalian teknik, pengendalian administrasi dan Alat pelindung diri.

Pengendalian teknik yang telah dilakukan yaitu mengganti kantong plastik yang digunakan dengan kantong plastik yang tebal sehingga potensi terkena tusukan/goresan jarum suntik dapat berkurang. Pengendalian administrasi yang telah dilakukan adalah pemberian pendidikan dan pelatihan tentang bekerja secara aman pada pekerja yang dilakukan satu tahun sekali. Pembuatan SOP untuk petugas pengelolaan limbah medis, misalnya, pemisahan limbah medis dan non medis, pemakaian penampungan sementara. Melakukan pemasangan prosedur cara penggunaan alat sesuai standart di setiap alat, pemasangan label pada bahan kimia berbahaya, pemeriksaan dan pemeliharaan incinerator, meski alat sudah tidak dipakai. Sedangkan untuk alat pelindung diri yang telah diterapkan oleh RS yaitu memberikan pakaian kerja, sarung tangan serta safety shoes.

\section{PEMBAHASAN}

Proses pengelolaan limbah medis benda tajam yang terdapat pada RS. X meliputi pemisahan, penampungan sementara, pengangkutan serta pemusnahan. Hal-hal yang perlu diperhatikan pada tiap proses pengelolaan limbah medis benda tajam yang ada di RS. X adalah pada proses pemisahan.

Berdasarkan hasil observasi yang telah dilakukan, didapatkan bahwa pada proses pemisahan dilakukan modifikasi penggunaan warna pada tempat sampah yang berlabel medis dan non medis untuk memilah-milah limbah dengan tempat yang sesuai, sehingga limbah dapat dipisah-pisahkan menurut jenis limbah. Hal ini sudah sesuai bahwa pada saat proses pemisahan limbah dipisahkan dari sumbernya, segala limbah yang memiliki risiko tinggi hendaknya di berikan label yang jelas dan pemakaian kantung plastik dengan 
Sachrina, et al. Upaya Pengendalian Risiko Pada Unit Pengelolaan Limbah Medis Benda Tajam di Rumah Sakit
JPH RECODE Maret 2018; 1 (2) : 98-108 http://e-journal.unair.ac.id/JPHRECODE warna yang berbeda, yang menunjukkan ke mana plastik harus diangkut untuk insenerasi atau dibuang (Adisasmito, 2007). Berbeda halnya pada proses pemisahan pada jarum suntik, ditemukan obyek kurang memperhatikan prosedur yang telah ditetapkan dalam hal pemisahan limbah medis benda tajam. Jarum suntik tidak dipisahkan dengan spetnya. Meskipun limbah medis benda tajam telah dipisahkan dari limbah medis lainnya tetapi adakalanya limbah medis benda tajam yang telah di masukkan kedalam box dibuang kedalam kantong plastik limbah medis dengan cara dituang dari box tersebut. Hal tersebut tidak sesuai dengan Peraturan Dirjen PPM \& PLP Depkes RI, 2002 tentang pedoman sanitasi limbah medis rumah sakit di Indonesia yaitu pada proses pemisahan limbah medis dengan limbah non medis harus dipisahkan (Departemen Kesehatan RI, 2002).

Penampungan sementara limbah yang telah dikumpulkan akan dipindahkan ke tempat penampungan limbah sementara yaitu berupa kontainer. Pada setiap ruangan poli dan irna sudah disediakan kontainer di depan ruangan untuk menghindari volume limbah yang dihasilkan setiap hari tidak sampai penuh sehingga tutup kontainer tidak dalam keadaan terbuka dan aman. Hal ini sesuai dengan Peraturan Dirjen PPM \& PLP Depkes RI, 2002 tentang syarat- syarat dalam memilih kontainer yaitu memiliki penutup yang dapat dibuka dengan mudah dan dapat ditutup tanpa menggunakan dan mengotori tangan pengguna, serta syarat pengangkutan, yaitu limbah medis termasuk limbah medis benda tajam hendaknya diangkut setiap hari atau setelah $2 / 3$ bagian dari kontainer terisi walaupun belum satu hari (Departemen Kesehatan RI, 2002).

Proses pengangkutan limbah dilakukan 2 kali dalam sehari yaitu pukul 07.30 pagi dan pada pukul 15.00 sore, hal ini dinyatakan sesuai dengan Peraturan Dirjen PPM \& PLP Depkes RI, 2002 yang telah menyatakan bahwa pengangkutan dilakukan setiap hari atau setelah $2 / 3$ bagian dari kontainer terisi walaupun belum sehari (Departemen Kesehatan RI, 2002). Apabila limbah tidak diangkut sebelum penuh dan mengakibatkan kontainer penuh sehingga limbah menumpuk dan tercecer. Keadaan ini akan membahayakan bagi orang yang berada di rumah sakit baik bagi pengunjung ataupun pekerja, karena kemungkinan kecelakaan akibat benda tajam akan sering terjadi.
Pemusnahan RS. $\mathrm{X}$ pemusnahan dilakukan dengan dikirim ke pihak ketiga yaitu di sebuah perusahaan pemusnahan limbah medis untuk memusnahkan. Limbah medis setiap pagi diangkut oleh pihak ketiga. Hal ini sesuai dengan peraturan Dirjen PPM \& PLP Depkes RI, 2004 disebutkan bahwa limbah medis benda tajam yang mempunyai risiko terkontaminasi dengan darah, cairan tubuh dari pasien penyakit infeksi maupun menular serta kontaminasi dengan bahan citotoksik sebaiknya dimusnahkan dengan incinerator apabila pihak RS tidak memiki incinerator maka pihak RS wajib mengirim limbah pada pengelolaan limbah pihak ketiga (Depnakertrans R.I, 2004).

Identifikasi bahaya merupakan proses yang dapat dilakukan untuk mengidentifikasi seluruh kejadian yang memiliki potensi sebagai penyebab kecelakaan dan penyakit akibat kerja yang mungkin akan timbul di suatu tempat kerja (Tarwaka, 2008). Pada kenyataanya, suatu organisasi seringkali mengalami kesulitan mengidentifikasi dan menentukan bahaya. Hal ini disebabkan begitu banyak kegiatan- kegiatan yang harus di identifikasi. Peneliti melakukan identifikasi bahaya pengelolaan limbah medis benda tajam di Rumah Sakit Islam Siti Hajar Sidoarjo menggunakan metode Job Safety Analysis (JSA), dimana dilakukan observasi bahaya yang ada pada setiap langkah kerja dan mencarikan upaya pengendalian. Hasil pembahasan dari identifikasi bahaya pengelolaan limbah medis benda tajam di RSI Siti Hajar Sidoarjo sebagai berikut.

Proses pemisahan limbah berupa benda padat yaitu jarum suntik, ampul dan botol infus yang dilakukan oleh petugas berpotensi bahaya yang teridentifikasi pada proses ini adalah tertusuk jarum atau tergores pecahan ampul pada saat melakukan pemisahan. Tertusuk jarum atau tergores merupakan suatu bahaya mekanis yang berasal dari peralatan mekanis atau benda yang bergerak dengan gaya mekanika baik yang digerakkan manual maupun dengan penggerak (Ramli, 2010). Pada saat melakukan observasi peneliti menemukan limbah medis dimasukkan pada tempat limbah non medis, diduga perawat kurang teliti pada saat membuang limbah. Sebaiknya limbah medis dan non medis diletakkan pada tempat yang tidak saling berdekatan meski sudah berlabel. Hal ini untuk 
menghindari keteledoran pada saat membuang sampah.

Pada saat melakukan observasi, peneliti menemukan kondisi lantai basah di ruang IGD diduga dari tumpahan cairan infus. Sebaiknya lantai harus dibersihkan pada waktu-waktu tertentu sehingga selalu dalam keadaan bersih. Potensi bahaya terpeleset karena lantai dalam keadaan basah dan licin. Hal tersebut belum sesuai dengan prinsip 5R yang ketiga yaitu Resik, sehingga kebersihan lantai, ruangan tetap terjaga, selalu bersih dengan adanya kegiatan pembersihan tempat kerja pada waktu-waktu tertentu.

Penampungan sementara pada RS. X yaitu menggunakan troli berfungsi untuk tempat penyimpanan limbah yang bersifat sementara, untuk kegiatan memasukkan dan mengeluarkan limbah pada troli dengan cara menutup dan membuka tutup troli yang dilakukan secara terus menerus sehingga potensi bahaya yang teridentifikasi pada proses ini bersumber dari tutup troli yang dilakukan pada saat memasukkan dan mengeluarkan limbah yaitu terjepit saat menutup dan membuka tutup troli. Sedangkan untuk penempatan troli yang tidak pada tempatnya dapat menggangu petugas atau keluarga pasien yang lalu lalang jalan melewati troli sehingga berpotensi menimbulkan bahaya terbentur dan berakibat lecet atau cidera ringan.

Hal tersebut belum sesuai dengan Peraturan Pemerintah No. 50 tahun 2012 tentang SMK3 mengenai potensi bahaya yaitu suatu keadaan baik pada mesin, pesawat, peralatan, orang, cara kerja, instalasi, bahan, proses produksi, sifat kerja dan lingkungan yang berpotensi menimbulkan beberapa macam kerugian, kerusakan, gangguan, kebakaran, kecelakaan, penyakit akibat kerja, peledakan, serta pencemaran (Presiden Republik Indonesia, 2012).

Pengangkutan di RS. X dilakukan di seluruh ruangan poli dan ruangan, petugas bertugas mengangkut limbah dari kontainer yang berada di setiap ruangan kemudian dipindahkan ke troli. Pada saat melakukan pemindahan kantong plastik dari kontainer ke troli dengan kondisi kantong plastik yang tipis akan berpotensi menimbulkan bahaya tertusuk/tergores pecahan botol ampul. Tertusuk jarum atau tergores merupakan suatu bahaya mekanis yang berasal dari peralatan mekanis atau benda bergerak dengan gaya mekanika baik yang digerakkan secara manual maupun dengan penggerak (Ramli, 2010).

Pemusnahan di RS. X diserahkan pada pihak ketiga yaitu bekerjasama dengan perusahaan pemusnahan limbah di Mojokerto untuk memusnahkan limbah medis. Hal tersebut sesuai dengan Kemenkes RI No.1204 tahun 2004, bagi rumah sakit yang tidak mempunyai insenerator, maka limbah medis harus dimusnahkan melalui kerjasama dengan rumah sakit atau pihak lain yang mempunyai insenerator untuk dilakukan pemusnahan (Depnakertrans R.I, 2004)

Penilaian risiko adalah suatu proses evaluasi risiko yang diakibatkan adanya bahaya dengan memerhatikan segala pengendalian risiko yang dimiliki serta menentukan apakah risikonya dapat diterima atau tidak (Matatula, 2008). Langkah-langkah yang biasa digunakan untuk penilaian risiko adalah mempersiapkan program penilaian risiko dengan membuat daftar seluruh tugas, proses dan area kerja yang memunculkan bahaya. Kemudian, daftar tersebut disusun secara berurutan mulai dari tingkat bahaya terbesar, serta membuat rencana program penilaian risiko. Setelah itu menerapkan program tersebut dengan mengikuti prosedurprosedur untuk mengurangi dan mengevaluasi setiap bahaya.

Mengidentifikasi bahaya dengan cara inspeksi keselamatan kerja dengan cara melakukan survey keselamatan umum ditempat kerja. Mengadakan patroli keselamatan kerja dengan cara mengidentifikasi bahaya disepanjang rute patrol yang diterapkan terlebih dahulu. Lalu mengambil sampel keselamatan kerja dengan melakukan pemeriksaan hanya untuk satu jenis bahaya, kemudian mengulanginya untuk bahaya yang lainnya. Mengaudit keselamatan kerja membuat hitungan jumlah bahaya berbeda yang ditemukan sebagai pembanding dengan audit yang serupa pada waktu yang sebelumnya dan yang akan datang. Setelah melakukan survei kondisi lingkungan, membuat laporan kecelakaan, melaporkan kondisi yang menimbulkan kecelakaan atau nyaris celaka. Meminta masukan dari para pekerja. Laporan dari media pers dan asosiasi perdagangan.

Menghilangkan atau mengurangi bahaya tindakan yang dilakukan adalah menghilangkan operasi atau material berbahaya. Bahaya yang tidak dapat 
dihilangkan dapat menggunakan dengan cara mengembangkan metode kerja yang lebih aman. Salah satunnya dengan menggunakan material-material alternatif yang lebih rendah bahayanya, melakukan evaluasi risiko-risiko residual yaitu dengan melakukan penilaian risiko yang mempertimbangkan tingkat atau ukuran bahaya yang dihadapi, waktu ekspos, jumlah orang yang terekspos, probabilitas peristiwa terjadi. mengevaluasi secara kualitatif, berdasarkan penaksiran pribadi (contohnya tinggi, sedang atau rendah), bersifat subjektif, dapat diberi nilai numerik atau secara kuantitatif, berdasarkan data laju kegagalan yang diterbitkan dan sering dicatat sebagai probabilitas, mengembangkan strategi pencegahan dengan cara menghilangkan perlengkapan, material, substansi atau metode kerja yang berbahaya. Setelah itu mensubstitusi perlengkapan, material, substansi atau metode kerja dengan yang lebih aman, mencegah ekspos atau kontak dengan menggunakan struktur kumbung, wadah atau sarana pelindung yang sesuai. mengendalikan ekspos atau kontak dengan cara membatasi akses atau waktu kontaknya dengan substansi, serta menyediakan PPE sebagai usaha terakhir.

Diperlukan pelatihan mengenai metode kerja yang baru dan penggunaan upaya pencegahan yang benar. Kemdian, memonitor penerapan tindakan pencegahan dengan melakukan upaya pencegahan atau metode kerja yang sedang digunakan, upaya pencegahan berjalan dengan efektif, serta metode kerja yang baru tidak menciptakan bahaya baru.

Mengoreksi dan menandai kemungkinan kelemahan upaya-upaya pencegahan tersebut. Kenudian, memeriksa kembali dan merevisi, serta memastikan bahwa metode yang telah dijalankan tersebut masih efektif. Apabila penilainnya menunjukkan tidak efektif maka perlu dilakukan upaya pembaharuan upaya pencegahan.

Penilaian risiko pengelolaan limbah medis benda tajam di RS. X didasarkan pada data-data di lapangan dan informasi serta nasehat dari para ahli di bidangnya dan mengacu pada metode pengkategorian risiko (2D Model). Hasil pengkategorian risiko tersebut sebagai berikut, pada proses pemisahan memiliki bahaya potensial tertusuk jarum/limbah medis benda tajam. Pada proses tersebut menghasilkan 1 kategori risiko yaitu tingkat risiko medium. Tingkat risiko medium dihasilkan dari perkalian antara Consequence dengan Probability menghasilkan nilai antara 5-9 (Tarwaka, 2008). Pada proses ini nilai risiko yang dihasilkan adalah 6 , artinya risiko yang ditimbulkan dari potensi bahaya tertusuk jarum bisa menyebabkan cidera atau sakit ringan dan kemungkinan terjadinya bisa beberapa kali.

Potensi bahaya terpeleset tersebut menghasilkan 1 kategori risiko yaitu tingkat risiko low. Tingkat risiko low dihasilkan dari perkalian antara Consequence dengan Probability menghasilkan nilai antara 1-4 (Tarwaka, 2008). Pada proses ini nilai risiko yang dihasilkan adalah 2, artinya risiko yang ditimbulkan dari potensi bahaya lantai licin dan terpeleset bisa menyebabkan cidera atau sakit yang parah dalam waktu yang lama tetapi kemungkinan terjadinya pada sekali waktu.

Potensi bahaya tergores pecahan botol ampul pada proses tersebut menghasilkan 1 kategori risiko yaitu tingkat risiko low. Tingkat risiko low dihasilkan dari perkalian antara Consequence dengan Probability menghasilkan nilai antara 2-4 (Tarwaka, 2008). Pada proses ini nilai risiko yang dihasilkan adalah 4, artinya risiko yang ditimbulkan bisa menyebabkan cidera atau sakit ringan dan kemungkinan terjadinya jarang atau terjadinya sekali waktu.

Penampungan sementara, potensi bahaya dapat tertusuk jarum/limbah medis benda tajam. Pada proses tersebut menghasilkan 1 kategori risiko yaitu tingkat risiko medium. Tingkat risiko medium dihasilkan dari perkalian antara Consequence dengan Probability menghasilkan nilai antara 5-9 (Tarwaka, 2008). Pada proses ini nilai risiko yang dihasilkan adalah 6 , artinya risiko yang ditimbulkan dari potensi bahaya tertusuk jarum bisa menyebabkan cidera atau sakit ringan dan kemungkinan terjadinya bisa beberapa kali. Risiko bahaya tangan terjepit, pada proses tersebut menghasilkan 1 kategori risiko yaitu tingkat risiko low. Tingkat risiko low dihasilkan dari perkalian antara Consequence dengan Probability menghasilkan nilai antara 0-1 (Tarwaka, 2008). Proses ini nilai risiko yang dihasilkan adalah 1, artinya risiko yang timbul tidak mengakibatkan cidera atau tidak memerlukan perawatan kesehatan.

Risiko bahaya terbentur Pada proses tersebut menghasilkan 1 kategori risiko yaitu tingkat risiko low. Tingkat risiko low 
dihasilkan dari perkalian antara Consequence dengan Probability menghasilkan nilai antara 1-4 (Tarwaka, 2008). Pada proses ini nilai risiko yang dihasilkan adalah 2 , artinya risiko yang timbul tidak mengakibatkan cidera atau tidak memerlukan perawatan kesehatan.

Pengangkutan terdapat 3 potensi bahaya yaitu pengangkutan yang kurang hati-hati, tangan terjepit dan terpeleset. Pada pengangkutan yang kurang hati-hati, proses tersebut menghasilkan 1 kategori risiko yaitu tingkat risiko low. Tingkat risiko low dihasilkan dari perkalian antara Consequence dengan Probability menghasilkan nilai antara 1-4 (Tarwaka, 2008). Pada proses ini nilai risiko yang dihasilkan adalah 2, artinya risiko yang timbul tidak mengakibatkan cidera atau tidak memerlukan perawatan kesehatan.

Potensi bahaya tangan terjepit pada proses tersebut menghasilkan 1 kategori risiko yaitu tingkat risiko low. Tingkat risiko low dihasilkan dari perkalian antara Consequence dengan Probability menghasilkan nilai antara 0-1 (Tarwaka, 2008). Pada proses ini nilai risiko yang dihasilkan adalah 1 , artinya risiko yang timbul tidak mengakibatkan cidera atau tidak memerlukan perawatan kesehatan.

Potensi bahaya terpeleset pada proses tersebut menghasilkan 1 kategori risiko yaitu tingkat risiko low. Tingkat risiko low dihasilkan dari perkalian antara Consequence dengan Probability menghasilkan nilai antara 1-4 (Tarwaka, 2008). Pada proses ini nilai risiko yang dihasilkan adalah 3 , artinya risiko yang ditimbulkan dari potensi bahaya lantai licin dan terpeleset bisa menyebabkan cidera atau sakit yang parah dalam waktu yang lama tetapi kemungkinan terjadinya pada sekali waktu.

Hasil penilaian risiko yang sudah dilakukan oleh peneliti pada proses pengelolaan limbah medis benda tajam di RS. $\mathrm{X}$, menunjukkan bahwa nilai risiko tertinggi adalah proses pemisahan dan penampungan sementara akibat tertusuk jarum/limbah medis benda tajam. Risiko tersebut masih dapat diterima karena nilai risikonya adalah 6 atau tergolong tingkat risiko medium. Harus menjadi prioritas utama dalam menyusun rencana pengendalian risiko. Sedangkan nilai risiko terendah adalah proses penampungan sementara dan pengangkutan dengan potensi bahaya tangan terjepit didapat nilai risiko 1 atau termasuk tingkat risiko low. Tingkat risiko tersebut dapat diabaikan dari rencana pengendalian namun tidak dapat dipungkiri dapat menjadi prioritas terakhir.

Prioritas pengendalian risiko sangat penting dilakukan karena terkait dengan anggaran biaya perusahaan untuk setiap pengendalian. Perusahaan tidak mungkin menyediakan dana yang besar untuk mengendalikan setiap risiko bahaya walaupun semua bahaya dapat menimbulkan kecelakaan (Ramli, 2010). Jadi perlu adanya urutan bahaya mana yang perlu dilakukan pengendalian terlebih dahulu. Oleh karena itu penting dibuat urutanbprioritas pengendalian bahaya berdasarkan hasil penilaian risiko yang sudah dilakukan (Ramli, 2010).

Pengendalian risiko di RS. X terdapat 3 yaitu, pengendalian teknik, pengendalian adsministrasi dan alat pelindung diri. Hal tersebut sudah sesuai dengan Peraturan Pemerintah No.50 Tahun 2012, tentang SMK3 mengenai upaya pengendalian bahaya dilakukan berdasarkan hasil penilaian risiko pada suatu pekerjaan melalui pengendalian teknik, administratif, dan penggunaan APD (Presiden Republik Indonesia, 2012).

Pengendalian risiko yang dilakukan pada pengelolaan limbah medis benda tajam di RS. X sudah sesuai dengan ketentuan tetapi pengendalian secara eliminasi dan substitusi tidak bisa diterapkan karena bahan kimia seperti klorin tidak bisa diganti dengan bahan lain. Pengendalian teknik atau rekayasa teknik termasuk merubah struktur objek kerja untuk mencegah seseorang terpapar potensi bahaya (Tarwaka, 2008). pengendalian teknik yang terdapat pada pengelolaan limbah medis benda tajam di rumah sakit yaitu kantong plastik yang digunakan untuk penampunampungan lebih baik digunakan yang tebal, tapi pada kenyataanya masih tipis walaupun itu sudah yang paling tebal. Pada pengendalian administrasi dilakukan dengan menyediakan suatu sistem kerja yang dapat mengurangi kemungkinan seseorang terpapar potensi bahaya (Tarwaka, 2008).

Pengendalian administrasi yang dilakukan di RS. X seperti pemberian pelatihan tentang bekerja secara aman. Pemberian pelatihan tentang bekerja secara aman diberikan pada semua tenaga kerja. Pemberian pelatihan tentang bekerja secara aman dilakukan pada semua tenaga Instalasi Sanitasi. Seperti yang terdapat dalam UU No.1 tahun 1970 pasal 9 tentang pembinaan pekerja tentang keselamatan kerja yaitu pengurus 
Sachrina, et al. Upaya Pengendalian Risiko Pada Unit Pengelolaan Limbah Medis Benda Tajam di Rumah Sakit
JPH RECODE Maret 2018; 1 (2) : 98-108 http://e-journal.unair.ac.id/JPHRECODE diwajibkan untuk menyelenggarakan kegiatan pembinaan untuk semua tenaga kerja yang berada dibawah pimpinannya, dalam pemberatasan kebakaran dan pencegahan kecelakaan kerja, peningkatan keselamatan dan kesehatan kerja, serta dalam P3K (Departemen Hukum dan Perundang-Undangan, 1970).

Upaya perbaikan pengendalian selanjutnya adalah membuat instruksi kerja pada Instalasi Sanitasi. Sebagaimana yang tercantum dalam PP No. 5 tahun 2012 pasal 11 ayat 2 butir c yaitu upaya dalam melaksanakan rencana K3 harus melakukan kegiatan dalam pemenuhan persyaratan K3 paling sedikit meliputi prosedur dan instruksi kerja. Selain itu, upaya lain adalah menyediakan kotak P3K beserta isinya yang sesuai dengan potensi bahaya yang ada.

Penggunaaan APD (Alat Pelindung Diri) merupakan alternatif terakhir setelah pengendalian secara teknis dan administratif tidak dapat menurunkan bahaya secara signifikan, serta perlu disadari dalam pemakaian APD perlu mengenali bahaya yang terpapar dan terlatih dalam menggunakannya serta pekerja harus sadar bahwa penggunaan APD tidak dapat menghilangkan bahaya, bila terjadi kerusakan maka pekerja akan terancam bahaya tersebut. Meskipun APD merupakan upaya pengendalian yang terakhir, setiap perusahaan juga harus menyediakan APD untuk menanggulangi bahaya yang ada di setiap pekerjaan. Instalasi Sanitasi sudah menyediakan APD yang berhubungan dengan pengelolaan limbah seperti, baju kerja, safety shoes, sarung tangan kulit, sarung tangan karet, pelindung pernapasan (masker). Hal tersebut sesuai dengan Permenakertrans No.PER.08/MEN/VII/2010 pasal 7 tentang (APD) alat pelindung diri, dimana pengusaha atau pengurus wajib menggunakan serta melaksanakan manajemen APD di tempat kerja (Menteri Tenaga Kerja dan Transmigrasi, 2010). Berdasarkan penelitian Paramita (2007) mengadakan pelatihan tentang pengelolaan sampah medis dan non medis secara berkala dan kedisiplinan penggunaan alat pelindung diri dapat meminimalisir kecelakaan kerja. Meskipun sudah diterapkan akan tetapi masih kurangnya kesadaran petugas tentang pentingnya penggunaan APD.

\section{SIMPULAN}

Terdapat bahaya Potensial pada pengelolaan limbah medis benda tajam di RS.
$X$ yaitu terdapat 9 bahaya potensial yang terdiri dari, pemisahan terdapat 3 bahaya potensial yaitu tertusuk, terpeleset, tergores. Penampungan sementara terdapat 3 bahaya potensial yaitu tertusuk, tangan terjepit dan terbentur. Pengangkutan terdapat 3 bahaya potensial yaitu tertimpa limbah medis, tergores pecahan botol dan tangan terjepit. Pada penilaian tingkat risiko didapatkan $7(77,8 \%)$ potensi bahaya dengan tingkat risiko Low (rendah), 2 (22,2\%) potensi bahaya sedangkan untuk tingkat risiko Medium (sedang) dan tidak ditemukan potensi bahaya pada tingkat risiko high (tinggi). Pengendalian risiko yang ada pada pengelolaan limbah medis benda tajam di RS. X sudah dilaksanakan dengan baik meliputi pengendalian teknik yaitu pengendalian pada alat, Pengedalian administrasi dan alat pelindung diri yang diterapkan pada pekerja. Disarankan rumah sakit memisahkan lokasi antara tempat sampah medis dan non medis agar mengurangi kesalahan dalam pemisahan, serta menyediakan sarung tangan yang adekuat dengan jumlah sesuai dengan pekerja untuk mengurangi potensi bahaya pada pekerja pengelolaan limbah.

\section{DAFTAR PUSTAKA}

Adisasmito, W. 2007. Sistem Manajemen Lingkungan Rumah Sakit. Jakarta: Grafindo Persada.

Alatas, M. 2013. Gambaran perilaku Perawat Dalam Membuang Limbah Medis dan Non Medis Di Rumah Sakit Umum Daerah Kabupaten Aceh Tamiang Tahun 2013. Jurnal Kebijakan, Promosi Kesehatan dan Biostatiskik, 2(1).

Blenkharn, J. I. 2006. Lowering standards of clinical waste management: Do the hazardous waste regulations conflict with the CDC's universal/standard precautions. Journal of Hospital Infection, 62(4), pp. 467-472. doi: 10.1016/j.jhin.2005.09.024.

Departemen Hukum dan PerundangUndangan. 1970. Undang-Undang Nomor 1 Tahun 1970 Tentang Keselamatan Kerja, Presiden Indonesia.

Departemen Kesehatan RI. 2002. Pedoman Sanitasi Rumah Sakit di Indonesia. Jakarta: Direktorat Jenderal PPM \& 
PPL dan Direktorat Jenderal Pelayanan Medik.

Depnakertrans R.I. 2004. Pedoman Pelaksanaan Pengelolaan Limbah Padat dan Limbah Cair di Rumah Sakit. Jakarta: Direktorat Pengawasan Norma keselamatan dan Kesehatan Kerja, Direktorat Jendral Pembinaan Pengawasan Ketenagakerjaan.

Matatula, J. 2008. Training Sistem Manajemen Kesehatan dan Keselamatan KerjaPersyaratan OHSAS 18001:2007.

Menteri Tenaga Kerja dan Transmigrasi. 2010. Peraturan Menteri Tenaga Kerja dan Transmigrasi R.I Nomor Per.08/Men/2010 Tentang Alat Pelindung Diri.

Notoatmodjo, S. 2005. Promosi Kesehatan Teori dan Aplikasi. Jakarta: Rineka Cipta.

Nursalam. 2008. Konsep Dan Teori Metodologi Penelitian Ilmu Keperawatan. Edisi 2', in Salemba Medika. doi: 10.1007/0-387-362746_24.

Paramita, N. 2007. Pengelolaan Sampah Rumah Sakit Pusat Angkatan Darat Gatot Soebroto. Jurnal Presipitasi: Media Komunikasi dan Pengembangan Teknik Lingkungan, 2(1), pp. 51-55. doi: https://doi.org/10.14710/presipitasi.v2i 1.51-55.

Pratiwi, Dyah dan Chatila Maharani. 2013. Pengelolaan Limbah Medis Padat pada Puskesmas Kabupaten Pati. Jurnal Kesehatan Masyarakat, 9(1), pp. 7484.

Presiden Republik Indonesia. 2012. Peraturan Pemerintah Republik Indonesia Nomor 50 tahun 2012 tentang Penerapan Sistem Manajemen Keselamatan dan Kesehatan Kerja.

Ramli, S. 2010. Pedoman Praktis Manajemen Risiko dalam Perspektif K3 OHS Risk Management. Jakarta: Dian Rakyat.

Sudiharti dan Solikhah. 2013. Hubungan Pengetahuan Dan Sikap Dengan Perilaku Perawat Dalam Pembuangan Sampah Medis Di Rumah Sakit Pku Muhammadiyah Yogyakarta. Jurnal Kesehatan Masyarakat (Journal of Public Health), 6(1), pp. 49-59. doi: 10.12928/kesmas.v6i1.1017.
Tarwaka. 2008. Keselamatan dan Kesehatan Kerja: Manajemen dan implementasi K3 di Tempat Kerja. Surakarta: Harapan Press. 